\title{
Experimental Investigation of Column Retrofitted with Steel Mesh and HPFRC under Cyclic Loading
}

\author{
Rupakumar C \\ M.E. Structural Engineering \\ SRM Valliammai Engineering college \\ Chennai, India
}

\author{
Swedha T \\ Assistant professor, Dept. of Civil Engineering \\ SRM Valliammai Engineering College \\ Chennai, India
}

\begin{abstract}
Retrofitting is the modification of existing damaged or undamaged structures to make them more resistant to seismic activity, ground motion, or soil failure due to earthquakes. The objective would be the judicious selection of retrofit materials and repairing schemes for a particular type of structures so that loss of life can be reduced as well as the integrity of the structures could be preserved. In the current study, experimental research was performed to improve the seismic strength and performance of reinforced concrete columns under cyclic load. This paper presents the retrofitting of column using the steel mesh and high performance fiber reinforced composite. The analytical work has been done using ANSYS software for the retrofitted column, in which results in deformation and stress analysis. The results clearly show with the use of steel mesh and HPFRC there is increase in seismic strength.
\end{abstract}

Keywords : Steel mesh, retrofitting, HPFRC, ANSYS

\section{INTRODUCTION}

Retrofitting is the modification of existing damaged or undamaged structures to make them more resistant to seismic activity, ground motion, or soil failure due to earthquakes. With better understanding of seismic demand on structures and with our recent experiences with large earthquakes near urban centers, the need of seismic retrofitting is well acknowledged. A column is a very important component in a structure. It is like the legs on which a structure stands. It is designed to resist axial and lateral forces and transfer them safely to the footings in the ground. Columns support floors in a structure. Slabs and beams transfer the stresses to the columns. So, it is important to design strong columns.

Retrofitting is the modification of existing structures to make them more resistant to ground motion, or soil failure due to earthquakes. Protection of the lives of building occupants in an earthquake is the main goal of the retrofit (this is referred to as "life safety" performance in building codes). The behavior of columns in tall structures is very important since column failures lead to additional structural failures and can result in total building collapse.

Seismic retrofit (or rehabilitation) strategies have been developed in the past few decades following the introduction of new seismic provisions and the availability of advanced materials (e.g. fiber-reinforced polymers (FRP), fiber reinforced concrete and high strength steel). The retrofit techniques are also applicable for other natural hazards such as tropical cyclones, tornadoes, and severe winds from thunderstorm. Whilst current practice of seismic retrofitting is predominantly concerned with structural improvements to reduce the seismic hazard of using the structures, it is similarly essential to reduce the hazards and losses from non-structural elements.
Retrofitting proves to be a better economic consideration and immediate shelter to problems rather than replacement of building. In retrofitting, the structure must be designed so it is in keeping with its purpose of use and is both safe and durable, with consideration given to the ease of retrofitting construction and post-retrofitting maintenance, as well as overall economy and environment- friendliness. This paper investigates the compressive behavior of the retrofitted column.

\section{MATERIALS AND METHODS}

\section{A. Raw materials and mix proportion}

Ordinary Portland cement of 43 grades is used for the investigation. Locally available coarse aggregates are taken and sieved to the required quantity of volume to the maximum nominal size of $10 \mathrm{~mm}$. Care is taken to arrive the size of coarse aggregate ranging from $4.75 \mathrm{~mm}$ to the maximum nominal size of $10 \mathrm{~mm}$.

Preliminary tests are carried as per IS standard on the material used for concrete like specific gravity for cement. For fine and coarse aggregates tests such as sieve analysis, specific gravity, impact value, crushing value are conducted as per standards. M30 grade of concrete is used for the casting of column specimen and the mix proportion is designed as per the standards according to the values which is arrived in the preliminary test. The mix proportion for M30 grade of concrete is $1: 1.52: 2.94$.

\section{B. Retrofitting materials}

In this paper, the materials used for retrofitting are steel mesh and HPFRC. A steel wire mesh is made up of uniformly crossed stainless steel in regular patterns and it has the thickness of $0.15 \mathrm{~mm}$ and the size of openings is $25 \mathrm{~mm}$.

High performance fiber reinforced composite is developing quickly to a modern structural material with a high potential. Fiber-reinforced concrete (FRC) is concrete containing fibrous material which increases its structural integrity. It contains short discrete fibers that are uniformly distributed and randomly oriented.

Both end hooked steel fibers are used for made the HPFRC and the properties of steel fibers are listed below.

Table- I Properties of steel fiber

\begin{tabular}{|c|c|} 
Table- I Properties of steel fiber \\
\hline PROPERTIES & VALUES \\
\hline Diameter & 0.75 \\
\hline Length of fiber & $60 \mathrm{~mm}$ \\
\hline Aspect ratio & 80 \\
\hline Tensile strength & $1050 \mathrm{MPa}$ \\
\hline Modulus of elasticity & $200 \mathrm{GPa}$ \\
\hline Specific gravity & 7.8 \\
\hline
\end{tabular}




\section{Casting of specimen}

The c/s dimension of the column is $200 \mathrm{~mm} \times 200 \mathrm{~m}$ and the height is $1 \mathrm{~m}$ and the column is designed as a short column. The ingredients of concrete such as cement, fine aggregate, coarse aggregate of maximum nominal size of $10 \mathrm{~mm}$ are weighed accurately using the platform weighing machine. The ingredients are mixed manually and adequate amount of water is added to the constituents of concrete. The mixing is done till to get uniform mix of concrete is obtained. After the casting of column specimen, it was get cured for 28 days in the curing tank.

\section{Retrofitting of column}

After 28 days of curing, the column is tested for pre-damage by applying cyclic loading. The load is continuously applied until the initial bending cracks are propagated. The tested conventional column has losing it load carrying capacity due to the application of cyclic loading and it is need to be retrofitted with steel mesh and HPFRC mortar to strengthen the column and it will improve the flexural strength and ductile capacity of the column. The loading details are mentioned in the table.

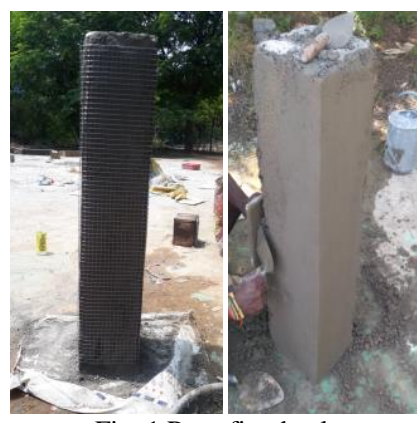

Fig. 1 Retrofitted column

The concrete surface is needed to be grooved to increase the structural bond between the concrete and the steel mesh. The retrofitting is done by first applying the layer of HPFRC mortar to make the bond between concrete surface and steel mesh. After the first layer of HPFRC mortar is applied, the steel mesh is needed to be tightly wrapped around the column. Use binding wires to tie the steel mesh. The steel mesh is tightly is wrapped and the HPFRC mortar is applied over the steel mesh at a thickness of $20 \mathrm{~mm}$.

\section{SOFTWARE ANALYSIS}

\section{A. General}

The ANSYS Workbench environment is an intuitive up-front finite element analysis tool that is used in conjunction with CAD systems and/or Design Moeller. ANSYS Workbench is a software environment for performing structural, thermal, and electromagnetic analyses.

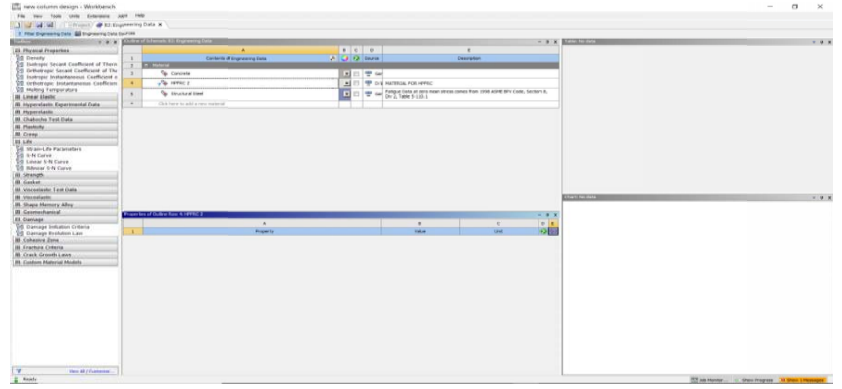

Fig.2 Assigning the materials in engineering data

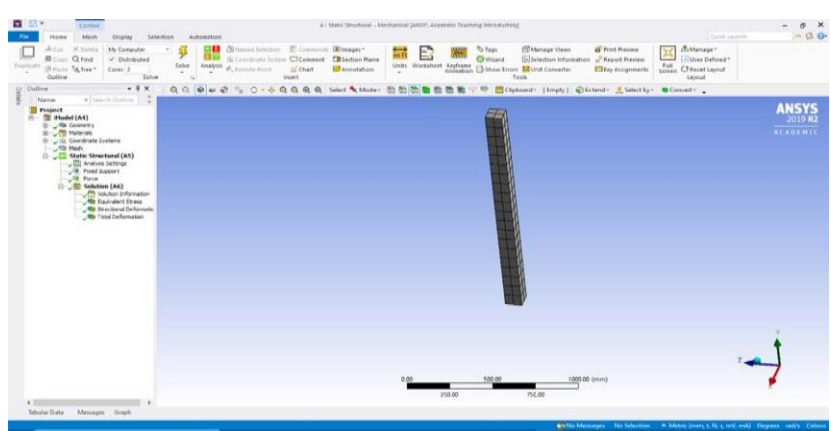

Fig.3 Geometry of column in design modeler

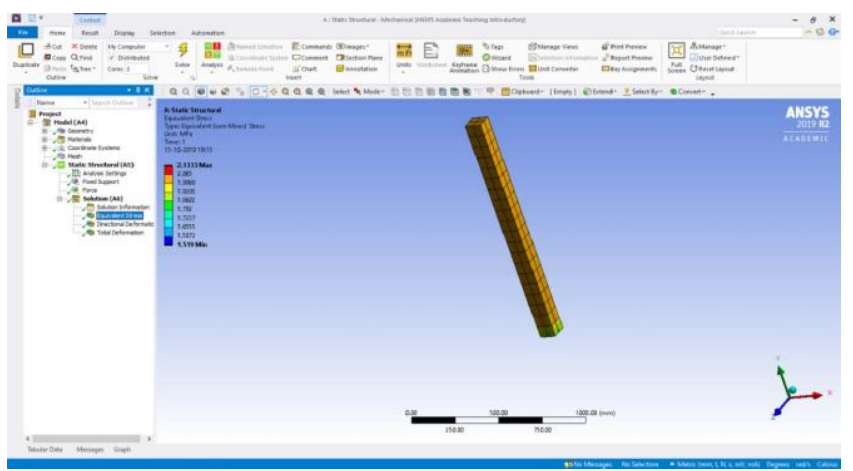

Fig.4 Equivalent Stress

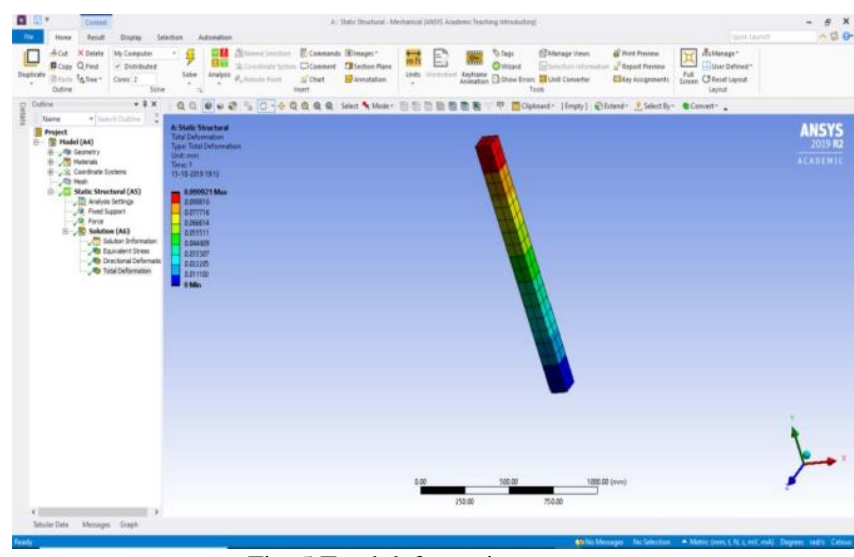

Fig. 5 Total deformation

\section{EXPERIMENTAL STUDY}

The Loading frame testing and the load with load cell are arranged in such a way to apply the cyclic loading over the column. Care is taken to avoid eccentricity during loading. Dial gauge is mounted where the deflections are required i.e. for measuring axial shortening, the deflection gauge is mounted at the bottom. 


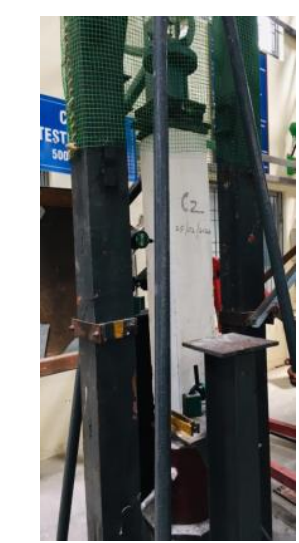

Fig. 6 Experimental test set up

\section{RESULT AND DISCUSSION}

The conventional column was tested under cycling loading and its load - deflection characteristics curves are given below.

Table- I: Test results of CC1

\begin{tabular}{|c|c|c|c|}
\hline Load $(\mathrm{KN})$ & Deflection(mm) & $\begin{array}{c}\text { Load } \\
(\mathrm{KN})\end{array}$ & Deflection(mm) \\
\hline 0 & 1 & 20 & 2.7 \\
\hline 20 & 2.4 & 40 & 4.7 \\
\hline 40 & 4.3 & 60 & 4.9 \\
\hline 60 & 4.7 & 80 & 5.1 \\
\hline 80 & 4.9 & 100 & 5.5 \\
\hline 100 & 5.1 & 120 & 6 \\
\hline 80 & 4.4 & 100 & 4 \\
\hline 60 & 4 & 80 & 3.9 \\
\hline 40 & 3.99 & 60 & 3.5 \\
\hline 20 & 2 & 40 & 3 \\
\hline 0 & 0.7 & 20 & 2.1 \\
\hline 10 & 1 & 0 & 0.4 \\
\hline
\end{tabular}

Fig. 8 Load vs deflection of CC1

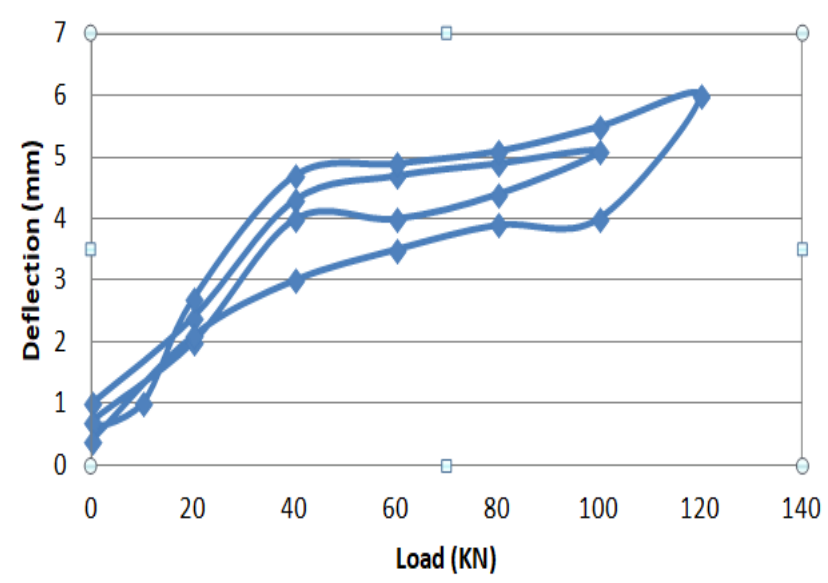

Table- II: Test results of CC2

\begin{tabular}{|c|c|c|c|}
\hline Load(KN) & Deflection(mm) & Load(KN) & Deflection(mm) \\
\hline 0 & 0 & 0 & 0 \\
\hline 50 & 2 & 50 & 4 \\
\hline 100 & 3 & 100 & 5 \\
\hline 150 & 3.5 & 200 & 6 \\
\hline 200 & 3.5 & 300 & 6.5 \\
\hline 200 & 3.2 & 400 & 7 \\
\hline 150 & 2 & 500 & 7.5 \\
\hline 100 & 1.25 & 600 & 7.6 \\
\hline 50 & 0.45 & 700 & 7.7 \\
\hline 0 & 0 & 700 & 7 \\
\hline 10 & 0.5 & 600 & 5.5 \\
\hline 50 & 2.5 & 500 & 4 \\
\hline 100 & 3.5 & 200 & 1.1 \\
\hline 200 & 4.5 & 0 & 0 \\
\hline 250 & 5 & 50 & 5.5 \\
\hline 300 & 5.2 & 200 & 7 \\
\hline 300 & 4.5 & 400 & 8 \\
\hline 250 & 3 & 500 & 8.5 \\
\hline 200 & 2 & 600 & 9 \\
\hline 100 & 0.9 & 700 & 9.1 \\
\hline 0 & 0 & 750 & 9.2 \\
\hline 50 & 3 & 800 & 9.3 \\
\hline 100 & 4.3 & 800 & 8.6 \\
\hline 200 & 5.5 & 750 & 7 \\
\hline 300 & 6 & 600 & 4 \\
\hline 400 & 6.25 & 500 & 2.8 \\
\hline 400 & 5.5 & 250 & 1 \\
\hline 300 & 3 & 0 & 0 \\
\hline 200 & 1.5 & & \\
\hline
\end{tabular}

Fig. 9 Load vs Deflection of CC2

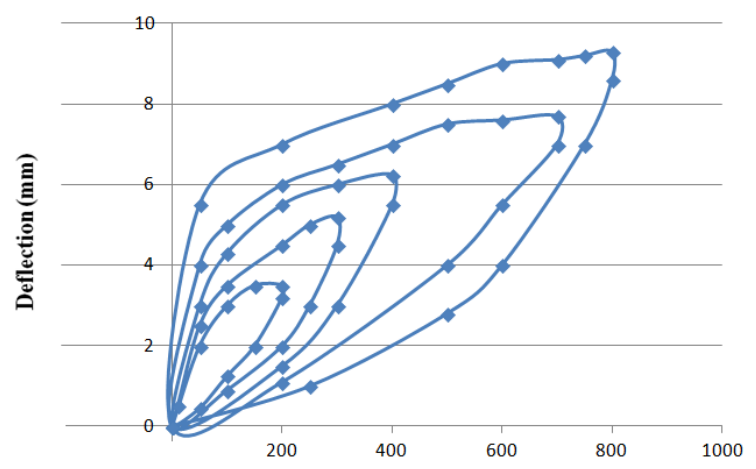

$\operatorname{Load}(\mathrm{KN})$ 
Table- III: Test results of RC

\begin{tabular}{|c|c|c|c|c|c|}
\hline $\begin{array}{l}\text { Load } \\
(\mathrm{KN})\end{array}$ & $\begin{array}{l}\text { Deflection } \\
\text { (mm) }\end{array}$ & $\begin{array}{l}\text { Load } \\
(\mathrm{KN})\end{array}$ & $\begin{array}{l}\text { Deflection } \\
\text { (mm) }\end{array}$ & $\begin{array}{l}\text { Load } \\
(\mathrm{KN})\end{array}$ & $\begin{array}{l}\text { Deflection } \\
\text { (mm) }\end{array}$ \\
\hline 0 & 0 & 300 & 4.5 & 650 & 7.3 \\
\hline 40 & 0.78 & 250 & 3.5 & 700 & 7.3 \\
\hline 80 & 1.54 & 200 & 2.8 & 700 & 6.9 \\
\hline 40 & 0.45 & 150 & 2 & 600 & 6.1 \\
\hline 0 & 0 & 50 & 0.5 & 500 & 5 \\
\hline 40 & 0.9 & 0 & 0 & 400 & 3.5 \\
\hline 80 & 1.7 & 60 & 2.8 & 300 & 2 \\
\hline 120 & 2.5 & 120 & 4 & 200 & 0.5 \\
\hline 160 & 3 & 180 & 4.5 & 100 & 0 \\
\hline 120 & 2.1 & 240 & 4.8 & 50 & 0 \\
\hline 80 & 1.1 & 300 & 5.2 & 0 & 0 \\
\hline 40 & 0.5 & 360 & 5.8 & 50 & 5 \\
\hline 0 & 0 & 420 & 5.8 & 100 & 5.5 \\
\hline 40 & 1.2 & 360 & 5 & 150 & 5.8 \\
\hline 80 & 2 & 300 & 4 & 250 & 6.3 \\
\hline 120 & 2.8 & 240 & 3 & 300 & 6.6 \\
\hline 160 & 3.3 & 180 & 1.5 & 400 & 7.1 \\
\hline 200 & 3.7 & 120 & 1 & 450 & 7.4 \\
\hline 240 & 3.95 & 60 & 0.45 & 500 & 7.6 \\
\hline 200 & 3.3 & 0 & 0 & 550 & 7.7 \\
\hline 160 & 2.9 & 80 & 4.1 & 600 & 7.8 \\
\hline 120 & 2.4 & 160 & 5 & 700 & 7.9 \\
\hline 80 & 1.6 & 240 & 5.5 & 800 & 8 \\
\hline 40 & 0.5 & 320 & 6 & 900 & 8 \\
\hline 0 & 0 & 400 & 6.5 & 900 & 7.4 \\
\hline 50 & 1.5 & 480 & 6.8 & 800 & 6.9 \\
\hline 100 & 2.8 & 560 & 6.8 & 700 & 6.2 \\
\hline 150 & 3.5 & 560 & 6 & 600 & 5.5 \\
\hline 200 & 3.8 & 400 & 4 & 500 & 4 \\
\hline 250 & 4.2 & 320 & 3 & 400 & 2.5 \\
\hline 200 & 3.5 & 240 & 1.5 & 300 & 1 \\
\hline 150 & 3 & 160 & 0.5 & 0 & 0 \\
\hline 100 & 2.3 & 80 & 0.5 & & \\
\hline 50 & 1 & 0 & 0 & & \\
\hline 0 & 0 & 50 & 4 & & \\
\hline 50 & 2 & 100 & 5 & & \\
\hline 100 & 3.5 & 200 & 5.5 & & \\
\hline 150 & 4 & 300 & 6.1 & & \\
\hline 200 & 4.2 & 400 & 6.8 & & \\
\hline 250 & 4.6 & 500 & 7.2 & & \\
\hline 300 & 5 & 550 & 7.3 & & \\
\hline 350 & 5.5 & 600 & 7.3 & & \\
\hline
\end{tabular}

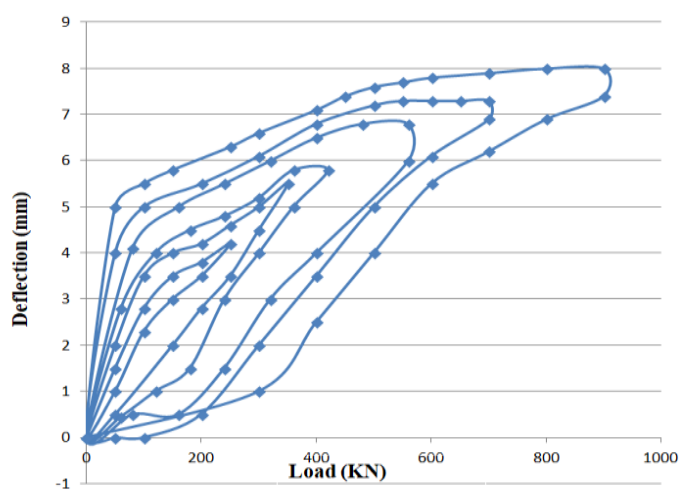

Fig. 10 Load vs deflection of RC (Retrofitted column)

The fig. 8 shows the load - deflection behaviour of conventional column $1(\mathrm{C} 1)$ and the first crack appeared at the load of $120 \mathrm{KN}$, during the second cylcic loaing and its corresponding deflection is $6 \mathrm{~mm}$, it is developed as the diagonal crack. The fig. 9 shows the load - deflection behaviour of conventional column 2 (C2) and the first crack appeared at the load of 180 , during the second cylcic loaing and the maximum ultimate load attained at the load of 800 KN. The fig.10 represents the Load - deflection characteristics of retrofitted column(RC). The initial crack appeared at the load of $280 \mathrm{KN}$ and the crack is propagated as the diagonal crack and the width of the crack is increased with increase in cyclic loading. The maximum ultimate load attained at the load of $910 \mathrm{KN}$.

For a retrofitted reinforced column, diagonal shear cracks were taken at the load of $250 \mathrm{KN}$. The width of cracks was gradually increased with increasing the number of cyclic load, the width of cracks was rapidly increased and the specimen was reached to failure at the ultimate load of $910 \mathrm{KN}$.

Table- IV Result of ultimate load

\begin{tabular}{|c|c|c|c|}
\hline Type & $\begin{array}{c}\text { First crack load } \\
(\mathrm{KN})\end{array}$ & $\begin{array}{c}\text { Ultimate load } \\
(\mathrm{KN})\end{array}$ & $\begin{array}{c}\text { Maximum } \\
\text { Deflection (mm) }\end{array}$ \\
\hline $\mathrm{CC} 1$ & 120 & - & 6 \\
\hline $\mathrm{CC} 2$ & 250 & - & 5.12 \\
\hline $\mathrm{CC} 3$ & 180 & 800 & 9.1 \\
\hline $\mathrm{RC} 1$ & 280 & 910 & 8 \\
\hline
\end{tabular}
made:

Based on the experimental test, the following points are

i. The first crack load in the retrofitted column(RC) is $280 \mathrm{KN}$ which is $35 \%$ greater than the conventional columns.

ii. Ultimate load of the retrofitted column is $910 \mathrm{KN}$ which is $13 \%$ greater than the normal conventional column.

iii. In comparison to the conventional reinforced concrete column, the developed strengthened column (RC) could provide excellent seismic improved responses in improving the load carrying and deformation capacities of the column.

\section{CONCLUSION}

Literature review has been done properly and most the data about retrofitting of the column and the uses of high performance fiber reinforced concrete in the retrofitting technique has been collected using the literature. Column size and properties of steel fibers and HPFRC have been fixed and the calculation of the maximum load has also been done. Using those results analytical design has been done in ANSYS Software, and the results have been obtained in the terms of deflection and maximum stresses. A series of reinforced concrete column specimens for seismic strengthening with applications of high performance fiberreinforced composites (HPFRC) combined with steel mesh were tested and investigated under cyclic load. The analysis work is done in ansys workbench software. The following conclusions can be made on the basis of the experimental results. To compare with a non-strengthened reinforced concrete column, the retrofitted column could lead not only to prevent shear failure of the column by minimizing the diagonal shear cracks but also to minimize bending cracks. In comparison to the conventional reinforced concrete column, the developed strengthened column (RC) could provide excellent seismic improved responses in improving the load carrying and deformation capacities of the column. Ultimate load of the retrofitted is $13 \%$ greater than the normal conventional column. Retrofitting using high- performance fiber reinforced concrete (HPFRC) and steel mesh was found to be adequate in restoring the strength. 


\section{REFERENCES}

[1] Aditya Singh Rajput, Umesh Kumar Sharma, Kaizad, 2019, Seismic retrofitting of corroded RC columns using advanced composite materials, Science Direct, Engineering Structures, vol 181, pp. 35-46.

[2] Chang-Geun Cho, Byung-Chan Han, Seung-Chan Lim, Noharu Morii, Jae-Whan Kim, 2018, Strengthening of reinforced concrete columns by High-Performance Fiber-Reinforced Cementitious Composite (HPFRC) sprayed mortar with strengthening bars. Science Direct, Engineering Structures, vol 202, pp. 1078-1086

[3] Gia Toai Truong, Jong-Chan Kim, Kyoung-Kyu Choi, 2017, Seismic performance of reinforced concrete columns retrofitted byvarious methods, Science Direct, Engineering Structures, vol 134, pp. 217-235.

[4] Gonzalo Ruano, Facundo Isla, Rodrigo Isas Pedraza, Domingo Sfer, Bibiana Luccioni, 2014, Shear retrofitting of reinforced concrete beams with steel fiber reinforced concrete, Science Direct, construction and building materials, vol 54, pp. 646-658

[5] Van Cao V, Ronagh H R,. 2014, Reducing the seismic damage of reinforced concrete frames using FRP confinement. Science Direct, Composite Structures vol 118: pp403-15.

[6] Chang-Geun Cho, Yun-Yong Kim, Luciano Feo, David Hui, 2012, Cyclic responses of reinforced concrete composite columns strengthened in the plastic hinge region by HPFRC mortar, Science Direct, composite structures, vol 94, pp. 2246-2253

[7] Niroomandi A, Maheri A, Maheri MR, Mahini SS. 2010, Seismic performance of ordinary RC frames retrofitted at joints by FRP sheets. Science Direct, Engineering Structures vol 32, pp6-36.

[8] Ha GG, Cho CG, 2008. Strengthening of reinforced high-strength concrete beam- column joints using advanced reinforcement details. Science Direct, Engineering Structures vol 60 pp.487-97.

[9] Triantafillou T, 2001, Seismic retrofitting of structures with fibre-reinforced polymers. Prog Struct Eng Mater, pp.57-65.

[10] Tsonos A G. 2008; Effectiveness of CFRP-jackets and RC-jackets in post- earthquake and pre earthquake retrofitting of beam-column sub assemblages. Science Direct, Engineering Structures, vol 30: pp.777-93 